\title{
PERANCANGAN DAN PEMBUATAN WEBSITE SEBAGAI APLIKASI E- COMMERCE PADA RISTY GROSIR GAMIS MALANG
}

\author{
Hepy Saputra, Taufik Rachman \\ Program Studi Teknik Informatika, STT Stikma Internasional Malang
}

\begin{abstract}
ABSTRAK
E-Commerce adalah kegiatan bisnis online yang bertujuan mengambil keuntungan. Masalah yang terjadi pada Risty Grosir Gamis kesulitan bagi pelanggan harus datang ke toko untuk memesan dan mengetahui informasi produk, pembuatan rekap data-data penjualan pada toko masih manual tanpa ada backup database serta area penjualan belum meluas hingga ke luar provinsi. Oleh karena itu solusi yang diberikan adalah dengan membangun sistem informasi e-commerce penjualan gamis pada Risty Grosir Gamis Malang. Sistem akan dirancang dan dibangun menggunakan metode waterfall yang terdiri dari beberapa tahapan yaitu, komunikasi, perencanaan, pemodelan, konstruksi dan implementasi sistem. Hasil dari pembuatan sistem informasi e-commerce penjualan gamis pada Risty Grosir Gamis Malang ini, para pelanggan dapat mencari informasi dan pemesanan produk melalui internet serta bagi pemilik toko dan karyawan toko dapat mengakses dan mengolah data dengan mudah.
\end{abstract}

Kata kunci : Sistem Informasi, E- Commerce, Waterfall

\section{PENDAHULUAN}

Pandemi COVID-19 telah mengubah berbagai aspek kehidupan manusia saat ini, terutama di bidang perdagangan. Ini menuntut semua elemen pedagang untuk beradaptasi dan melanjutkan proses jual beli. Proses jual beli online menjadi solusi efektif untuk mengurangi penyebaran virus COVID-19 karena pembeli tidak perlu mendatangi tempat/toko untuk melakukan pembelian.

Risty Grosir Gamis Malang merupakan distributor dan toko yang menjual berbagai jenis produk pakaian jadi di Kota Malang. Risty Grosir Gamis Malang sudah memulai usahanya sejak tahun 2018, dimulai dari menjualkan produk (reseller) sampai sekarang bisa membuat dan memasarkan produknya sendiri. Selama ini di Risty Grosir Gamis Malang hanya memasarkan melalui media sosial yaitu Instagram tetapi masih kurang efektif untuk memperkenalkan produknya ke ranah yang lebih luas.

Selama ini di Risty Grosir Gamis Malang masih melakukan pencatatan penjualan dengan proses manual tanpa ada input data di komputer, sehingga sering kali banyak masalah yang harus dihadapi terutama dalam hal pencatatan penjualan maupun perhitungan stok produk. Semua proses penjualan dicatat dalam buku yang kurang efektif karena belum ada softcopy atau softfile apabila ada masalah pada buku tersebut seperti rusak atau tulisan yang kurang jelas maka akan menjadi kendala yang cukup merugikan.

Website e-commerce merupakan sebuah solusi bagi Risty Grosir Gamis Malang agar dapat bersaing secara global. Menggunakan website e-commerce sebagai salah satu media penjualan dan promosi, maka akan memperluas daerah pemasaran produk dan memudahkan pembeli untuk memilih dan memesan produk tersebut sehingga dapat meningkatkan omzet penjualan toko tersebut. Dengan adanya website tersebut sebagai aplikasi untuk mempermudah penyimpanan laporan penjualan sehingga lebih efisien dalam pencatatan laporan penjualan maupun perhitungan stok produk dan memperluas area pemasaran produk. Berdasarkan uraian latar belakang diatas penulis tertarik dan bermaksud untuk menyusun Tugas Akhir ini dengan tema Perancangan Dan Pembuatan Website Sebagai Aplikasi E-Commerce Pada Risty Grosir Gamis Malang.

\section{TINJAUAN PUSTAKA}

Risty Grosir Gamis Malang memulai usaha produksi sendiri sejak 2018 dan merupakan salah satu produsen busana gamis yang tekenal murah namun mempunyai kualitas yang bagus dan model yang kekinian.

Risty Grosir Gamis Malang berlokasi di Jalan Bido Nomor 15 Sukun, kota Malang.

Ditempat tersebutlah semua proses produksi maupun penjualan berlangsung, mulai dari memilih dan memotong bahan, menjahit, packing, sampai pengiriman.

\subsection{Sistem Penjualan}

Penjualan secara umum dapat didefinisikan sebagai sekumpulan hal atau kegiatan atau elemen yang saling bekerja sama atau yang dihubungkan dengan cara-cara tertentu sehingga membentuk suatu kesatuan untuk melaksanakan suatu fungsi guna mencapai suatu tujuan. Penjualan adalah proses pertemuan antara penjual dan pembeli, perubahan keputusan pembeli yang dilaksanakan seorang penjual.

Penjualan juga bisa didefinisikan sebagai salah satu kegiatan dalam perekonomian yang mengakibatkan berpindahnya hak milik dari penjual kepada pembeli yang menerima imbalan tertentu sesuai dengan yang telah disepakati.

Sistem penjualan terbagi menjadi 2 yaitu:

- Sistem Tunai 
Merupakan transaksi yang apabila barang dan jasa diserahkan kepada pembeli setelah perusahaan menerima uang dari pembeli

- Sistem Transfer

Sistem Transfer adalah transaksi penjualan yang apabila pelanggan melakukan suatu order. Untuk pengiriman produk atau penyerahan jasa kepada pelanggannya ini menunggu setelah proses konfirmasi dari pelanggan bahwa pelanggan tersebut telah memenuhi syaratnya.

\subsection{Pengertian E-Commerce}

E-Commerce secara umum dapat diartikan sebagai proses transaksi jual beli secara elektronik melalui media internet. Menurut Mariza Arfina dan Robert Marpaung e-commerce atau yang lebih dikenal dengan e-com dapat diartikan sebagai suatu cara berbelanja atau berdagang secara online atau direct selling yang memanfaatkan fasilitas Internet dimana terdapat website yang dapat menyediakan layanan.

E-commerce dapat didefinisikan dalam beberapa perspektif antara lain :

- Perspektif Komunikasi

Pada perspektif ini E-commerce merupakan kemampuan untuk meyampaikan produk, jasa, informasi atau pembayaran via Network seperti internet atau www (World Wide Web).

- Perspektif Interface

E-commerce melibatkan aneka informasi dan pertukaran transaksi.

- Perspektif Proses Bisnis

E-commerce melibatkan aktifitas yang secara langsung mendukung perdagangan secara elektronik dengan menggunakan koneksi Network.

- Perspektif Online

E-commerce adalah lingkungan elektronik yang memungkinkannya untuk memberli dan menjual produk, jasa dan informasi pada internet.

- Perspektif Struktural

E-commerce melibatkan banyak media seperti data, teks, web page dan Internet.

\section{METODE PENELITIAN}

\subsection{Analisis Sistem Yang Berjalan}

Pada gambar 1 pelanggan datang ke toko untuk memesan produk kepada karyawan toko, pelanggan datang ke toko untuk memesan produk jika produk tersedia maka pemesanan akan dilanjutkan, dan jika tidak pemesanan selesai.

Jika pemesanan dilanjutkan dengan membuat pemesanan dibuatkan nota pembelian atau kwitansi oleh pelanggan satu untuk karyawan dan satu lagi diarispkan setelah mendapatkan nota pembelian maka pelanggan melakukan pembayaran kemudian karyawan menerima pembayaran jika produk telah dibayar pelanggan menerima produk yang dipesan tersebut.

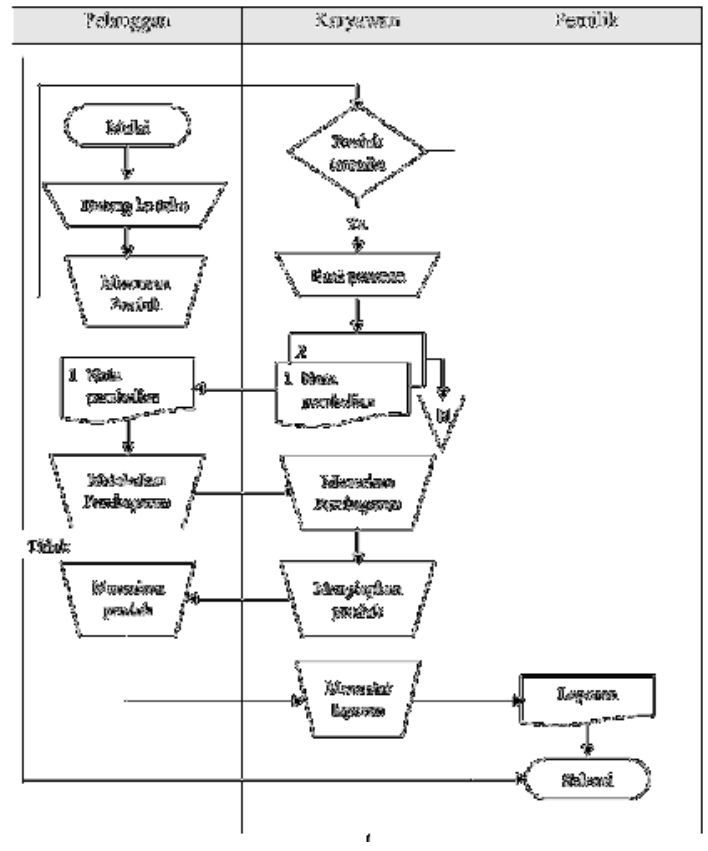

Gambar 1. Flowchart System Yang Sedang Berjalan

\subsection{Pemecahan Masalah}

Dari permasalahan yang terjadi saat ini yaitu semua data masih belum disimpan dalam sebuah database karena hanya dicatat dalam buku catatan. Saat mencari informasi harus mencari data yang disimpan pada buku catatan. Selain itu, kendala yang dirasakan pelanggan adalah jarak yang jauh dari toko dan bagi pelanggan yang memiliki kesibukan dalam kegiatan sehari-hari tidak memungkinkan harus datang ke toko, sehingga pelanggan tidak sempat datang untuk berbelanja. Proses seperti ini mengakibatkan kurang efisien karena menguras tenaga dan waktu yang mengharuskan pelanggan datang ke toko untuk memesan dan mengetahui informasi produk

Agar dapat memudahkan pekerjaan tersebut, maka diperlukan sistem informasi e-commerce penjualan gamis pada Risty Grosir Gamis Malang agar dalam mengakses informasi dapat dilakukan dengan cepat, serta memudahkan pelanggan untuk bertransaksi kapan saja dan dimana saja yang tidak mengharuskan pelanggan datang ke toko

\subsection{Analisis System}

Analisis sistem dilakukan untuk memberikan gambaran aliran data yang ada pada program sistem informasi yang akan dibangun. Tahapan-tahapan yang ada yaitu dengan mengkonfigurasi dari komponen-komponen perangkat lunak dan perangkat keras suatu sistem. Adapun sebagai alat bantu yang digunakan untuk menggambarkan atau memodelkan sistem secara umum yang akan dibangun yaitu menggunakan DFD 


\subsection{Context Diagram (CD)}

Diagram konteks menggambarkan ruang lingkup suatu system. Diagram konteks menunjukkan semua entitas luar yang menerima informasi dari system atau memberikan informasi ke sistem, berikut adalah diagram konteks pada sistem pembuatan website ecommerce ditunjukkan pada Gambar 2.

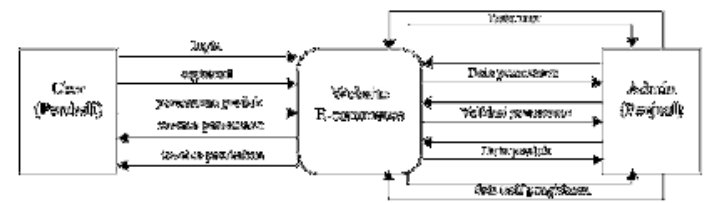

Gambar 2. Context Diagram

Dalam diagram konteks pada gambar 2 terdapat dua entitas yang menunjang proses-proses yang terdapat pada E-commerce penjualan gamis Risty Grosir Gamis Malang yaitu admin sebagai pengelola web dan user sebagai pembeli.

\subsection{Data Flow Diagram (DFD) Level 1}

Data Flow Diagram level 1 (DFD level 1) yang merupakan pengembangan dari context diagram. Memberikan pandangan menyeluruh mengenai sistem yang ditangani, menunjukkan fungsi atau proses yang ada disistem.

Data Flow Diagram (DFD) Level 1 yang menampilkan secara mendetailo proses-proses ditunjukkan pada Gambar 3.

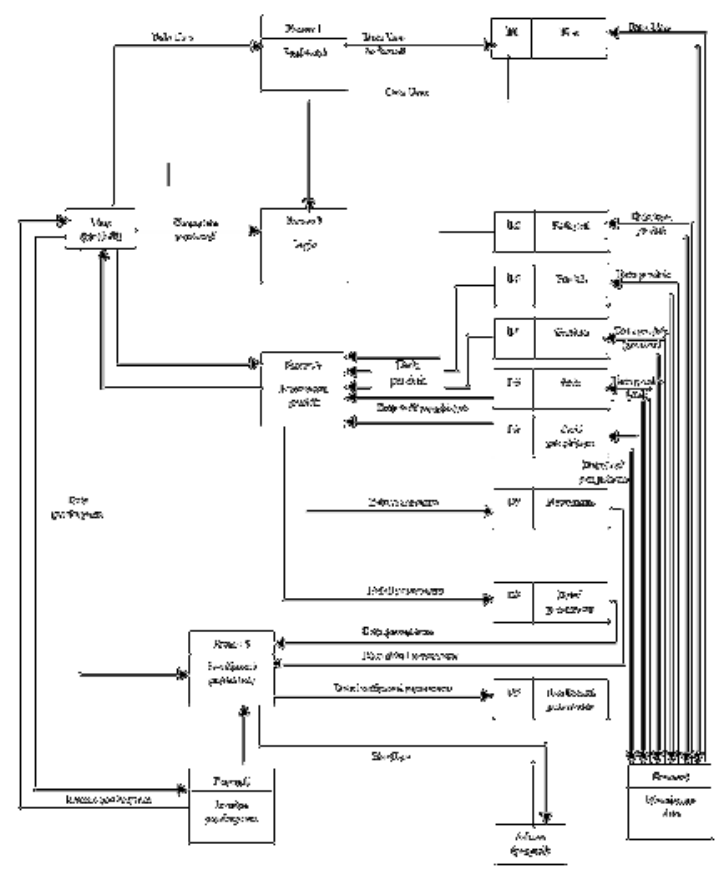

Gambar 3. Data Flow Diagram (DFD) Level 1

Pada gambar 3. DFD level 1 dijelaskan bahwa ada 6 proses. Proses tersebut terdiri dari registrasi pelanggan, login pelanggan, pemesanan produk, manajemen data, konfirmasi pemesanan, dan invoice pembayaran.

\subsection{DFD level 2 Proses 3 (Proses Pemesanan Produk)} Data Flow Diagram level 2 yang merupakan pengembangan dari Proses 3, Data Flow Diagram level 2 pemrosesan pemesanan produk oleh user ditunjukkan pada Gambar 4

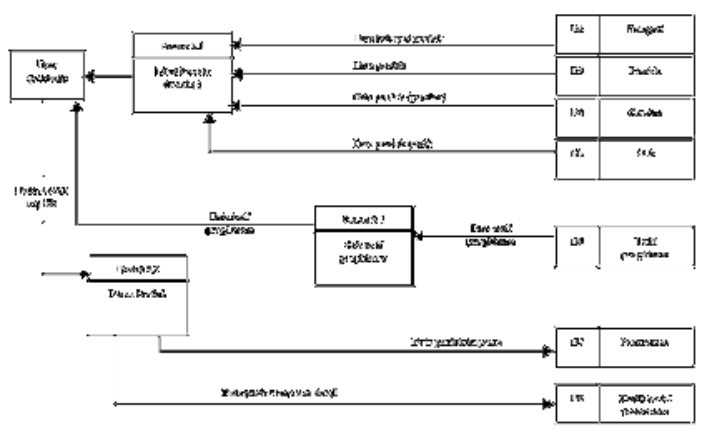

Gambar 4. DFD Level 2 Proses 3 (Proses Pemesanan produk)

\section{7. (DFD) Level 2 Proses 4 (Proses Manajemen Data)}

Data Flow Diagram level 2 yang merupakan pengembangan dari Proses 4, Data Flow Diagram level 2 pemrosesan admin ditunjukkan pada Gambar 5 .

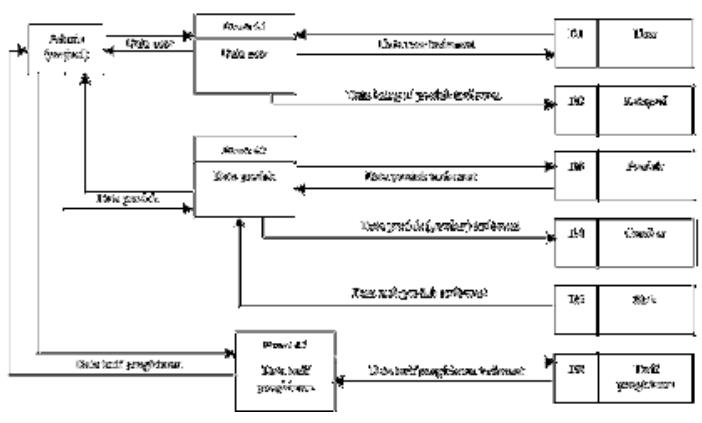

Gambar 5. DFD Level 2 Proses 4 (Proses Manajemen Data)

\subsection{DFD Level 2 Proses 5 (Proses Konfirmasi Pemesanan)}

Data Flow Diagram level 2 yang merupakan pengembangan dari Proses 5. ditunjukkan pada Gambar 6.

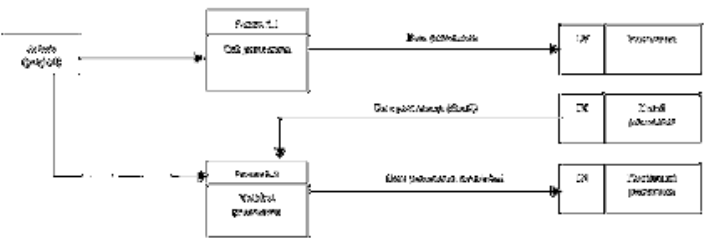

Gambar 6. DFD Level 2 Proses 5 (Proses Konfirmasi Pemesanan) 


\subsection{ERD (Entity Relationship Diagram)}

Proses perancangan database menggunakan ERD (Entity Relationship Diagram) ditunjukkan pada Gambar 7.

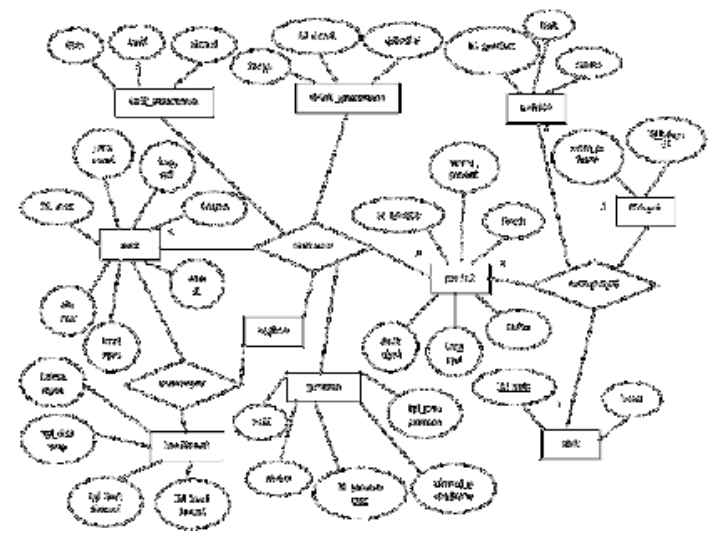

Gambar 7. ERD (Entity Relationship Diagram)

\subsection{Relationship (Diagram Skema)}

Tabel saling berelasi dalam website e-commerce ini. Relasi antar tabel ditunjukkan pada Gambar 8.

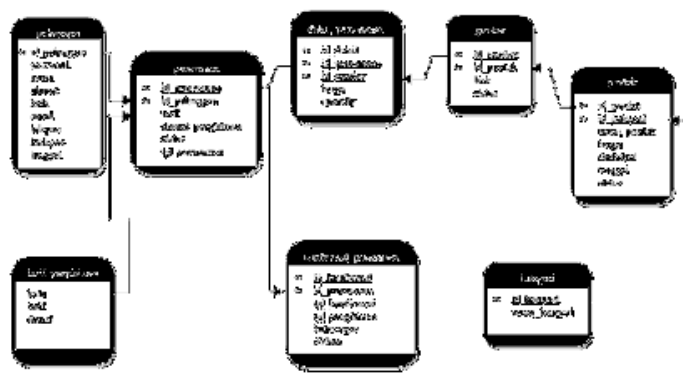

Gambar 8. Relationship (Relasi Antar Tabel)

\section{HASIL DAN PEMBAHASAN}

\subsection{Halaman Utama Header}

Halaman Utama Header berisi Icon Toko serta navbar menu Home, Belanja, Notifikasi, Informasi Persyaratan Penjual dan Pengiriman, serta Menu Login atau Registrasi. Pada halaman ini juga berisi Slider Banner untuk promo yang dapat di atur link maupun waktu kapan slider tersebut aktif.

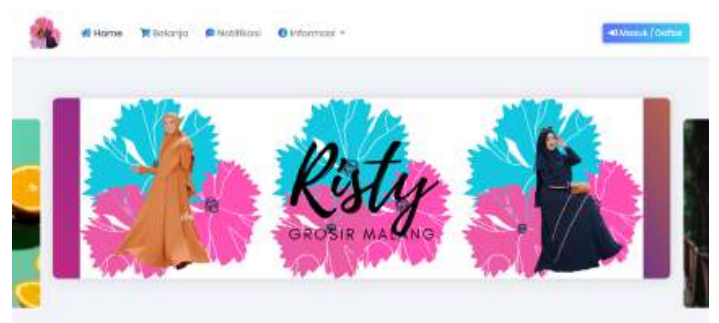

Gambar 9. Halaman Utama Header

\subsection{Halaman Utama Kategori}

Halaman Utama Kategori berisi icon menu kategori produk serta banner promo link instagram Risty Grosir Gamis Malang.

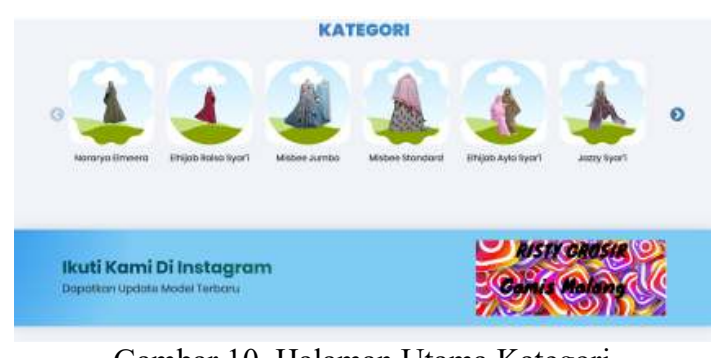

Gambar 10. Halaman Utama Kategori

\subsection{Halaman Utama Display Produk}

Halaman Utama Display Produk berisi produkproduk pilihan yang dijual di Risty Grosir Gamis Malang.

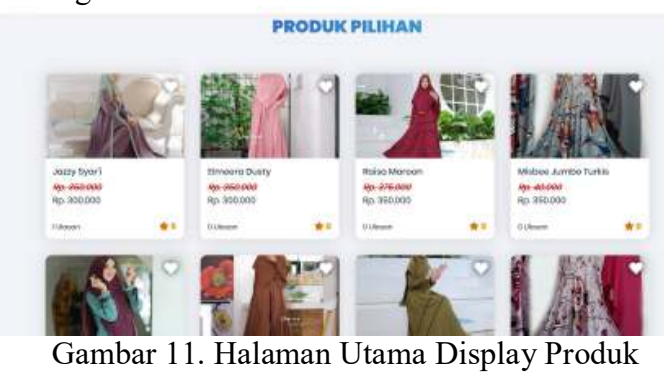

\subsection{Halaman Utama Berita Terkini}

Halaman Utama Berita Terkini berisi berita atau blog yang bisa di input oleh admin, juga bisa berisi link berita.

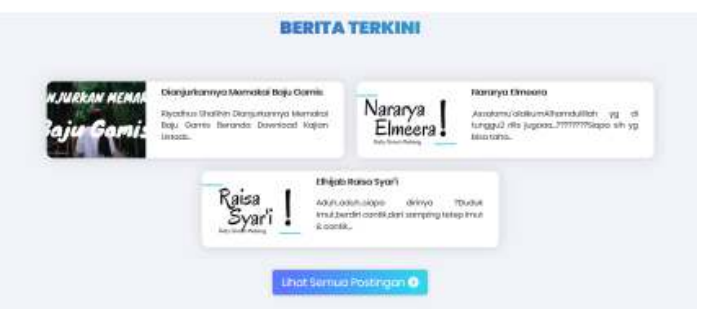

Gambar 12. Halaman Utama Berita Terkini

\subsection{Halaman Keranjang Belanja}

Halaman Keranjang Belanja adalah halaman yang menyimpan daftar belanja pelanggan sebelum melakukan pembayaran, disini pelanggan bisa mengupdate jumlah maupun menghapus produk.

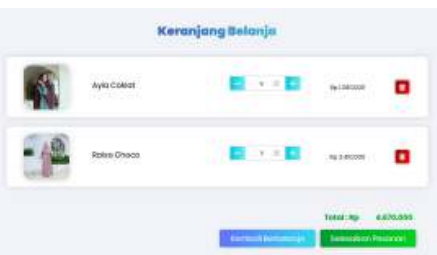

Gambar 13. Halaman Keranjang Belanja 


\subsection{Halaman Pembayaran}

Halaman Pembayaran adalah halaman untuk melakukan pembayaran sesuai dengan nominal jumlah harga produk ditambah ongkos kirim. Pelanggan juga dapat memakai voucher yang tersedia untuk mendapat potongan harga produk atau potongan ongkos kirim. Pelanggan juga bisa melakukan pembayaran dengan checkout melalui whatsapp yang terhubung langsung ke admin toko. Pelanggan juga bisa menambah alamat dropship.

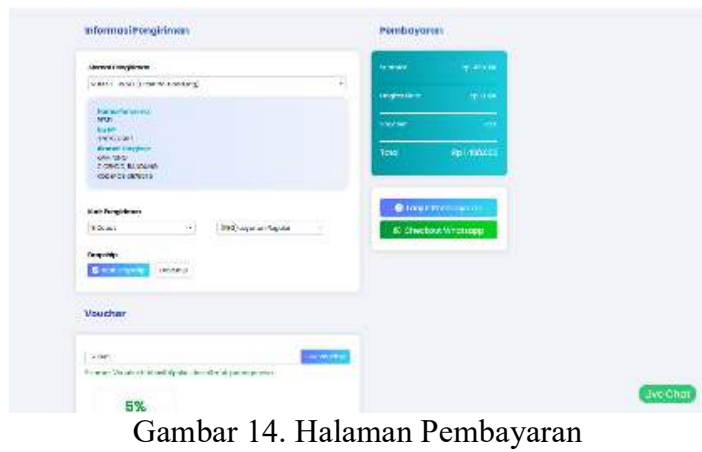

\subsection{Halaman Status Pesanan}

Halaman Status Pesanan berisi status pesanan, apabila pelanggan sudah melakukan transfer bisa mengupload bukti pembayaran dan pesanan akan segera diproses. Setelah produk dikirim oleh Admin toko akan menginput resi yang bisa ditracking untuk mengetahui posisi produk yang telah dikirim kurir.

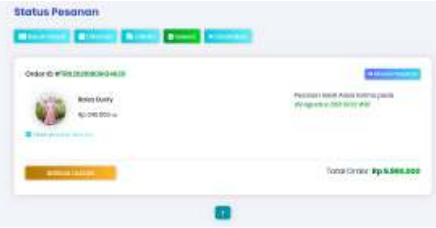

Gambar 15. Halaman Status Pesanan

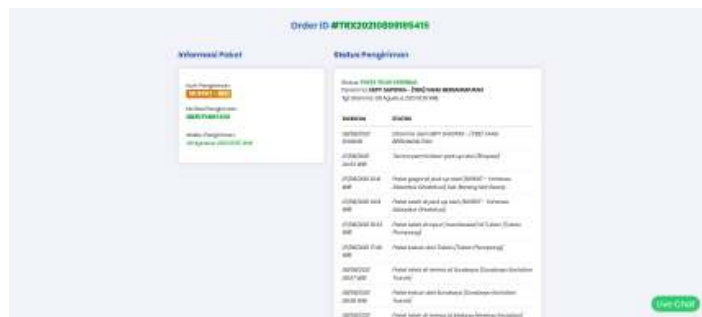

Gambar 16. Halaman Status Pesanan Tracking Resi

\section{KESIMPULAN DAN SARAN}

\subsection{Kesimpulan}

Kesimpulan dari uraian hasil dan pembahasan di atas, bahwa website e-commerce Risty Grosir Gamis Malang sudah dapat dibuat menggunakan PHP dan database MySQL. Kelebihan dari pemesanan produk dari website yaitu:

1. Pengunjung atau pelanggan mendapat informasi produk yang detail seperti foto produk, harga, serta deskripsi produk dan pelanggan dapat langsung memesan produk melalui website ini.

2. Admin toko dapat mengontrol ketersediaan jumlah stok produk melalui halaman dashboard produk.

3. Admin toko dapat melihat atau mencetak laporan penjualan lebih detail berdasarkan periode waktu tanpa takut kehilangan catatan karena disimpan di database server

\subsection{Saran}

Berdasarkan kesimpulan yang diperoleh maka penulis mempunyai saran-saran sebagai berikut:

1. Konfirmasi pembayaran belum dapat ditangani oleh sistem secara otomatis, maka perlu dibuat pengembangan sistem lebih lanjut untuk memudahkan transaksi pembelian.

2. Sistem register dan login masih manual, belum ada notifikasi email ataupun whatsapp untuk metode verifikasi.

3. Belum ada sistem preorder untuk memesan produk saat masih dalam proses produksi, pelanggan hanya bisa memesan produk yang tersedia.

4. Content website e-commerce perlu ditambah untuk menarik lebih banyak pengunjung atau pembeli.

\section{DAFTAR PUSTAKA}

[1] Handayani, S. P. M., \& Purnama, B. E. (2013). Pembuatan website e-commerce pada distro java trend. In Seruni-Seminar Riset Unggulan Nasional Informatika dan Komputer (Vol. 2, No. 1).

[2] Imansyah, M. (2003). PHP dan MySQL untuk Orang Awam. Palembang: CV. Maxikom.

[3] Kendall, K.E. dan Julie E. Kendall. (2003). Analisis dan Perancangan Sistem. Edisi Terjemahan. PT Intan Sejati: Klaten.

[4] Nugroho, B. (2004). Aplikasi Pemograman Web Dinamis dengan PHP dan MySQL. Yogyakarta: Gava Media.

[5] Prasetyo, DD. (2003). Tip dan trik Kolaburasi PHP dan MySQL untuk membuat Web Database yang Interaktif. Jakarta: Elex Media Komputindo.

[6] Pressman, R.S. (2002). Rekayasa Perangkat Lunak. Buku Satu Edisi Terjemahan. Andi: Yogyakarta.

[7] Sanjaya, Wisnu dan Ridwan Sanjaya. Membangun Kerajaan Bisnis Online, Jakarta: Elex Media Kompitindo, (2009)

[8] Saputra, Agus dan Feni Agustin. Membangun Sistem Aplikasi E-Commerce dan SMS. Jakarta: Elex Media Kompitindo, (2012)

[9] Sarwono, Jonathan dan K Prihartono, A.H. Perdagangan Online: Cara Bisnis di Internet. Jakarta: Elex Media Kompitindo, (2012).

[10] Wibowo, J. (2008). Perancangan dan Pembuatan Website sebagai Aplikasi e- 
commerce pada PD UTAMA Semarang (Doctoral dissertation, Prodi Akuntansi Unika Seogijapranata).

[11] Wibowo, N. S. (2012). Perancangan dan Pembuatan Website sebagai Aplikasi ecommerce pada Indo Veterinary (Doctoral dissertation, Prodi Akuntansi Unika Soegijapranata).

[12] Yudonugroho, (2010), "Database". scribd, didownload dari http://www.scribd.com/doc/30914906/Pengertia n-Database. 